Of Flies, Mice and Men

\author{
by François Jacob \\ Harvard University Press, \$24, xxx pp. \\ ISBN: 0-674-63111-0, 1998
}

Reviewed by Beatrice Renault

Associate Editor, Nature Medicine email: b.renault@natureny.com

Of Flies, Mice and Men is the English version of a book published in 1997 by François Jacob, the grand old man of French science. Jacob had an extraordinary career in which he collaborated with many of the most gifted scientists of the last 50 years, and his new book is a very personal journey through the turbulent and eventful twentieth century, encompassing scientific discoveries, political themes and historical vignettes. This is a record of his reflections on science's role in our society and its limitations.

Conversations with eminent colleagues such as Jacques Monod, Sydney Brenner and Seymour Benzer are recalled, and personal scientific endeavors are recounted. The book's main aim is to explain key concepts in biology, and indeed of science in general, centered on the role of the scientist, travelling down a few 'blind alleys' along the way-for example, the 'Lysenko affair' in Russia: Trofim Lysenko was a pseudo-scientist who, in the middle of the twentieth century, managed to impose on the entire Eastern bloc his theory based on the inheritance of acquired characteristics. The consequences were disastrous for Russian genetic research and for the agricultural development of the then-socialist countries, but fortunately inspired our author, pushing him towards the study of heredity.

Jacob has been one of the founding fathers of molecular biology, winning a Nobel Prize in 1965 with Jacques Monod and Andre Lwoff for their contribution to our understanding of the logic underlying the expression of genetic information in bacteria. It is not surprising, therefore, that a central thread of gen etics pervades the entire text. Greek philosophers from 200-300 BC were apparently the first to discuss the concept of heredity. Indeed, Daedalus, Prometheus and other heroes of Greek mythology are presented as entries at the beginning of each chapter, accompanied by poems and citations from literature and philosophy. AsJacobs points out, genetics is the study of that which makes related individuals alikeand

different at the same time. We know that only very recently genetics developed as a basic science with new, autonomous principles. In fact, William Bateson coined thenew term 'genetics' in 1906 for what was then perceived as an entirely new discipline. For Jacob, however, the manipulation of DNA, or genetic engineering, is a key step, a turning point in the history of genetics. A few decades have sufficed for the field to quickly evolve, diversify and play a growing part in our economy, our politics, our ethics and our health. Thetools of genetics areintegrated today into all biological disciplines from the study of evolution, development,

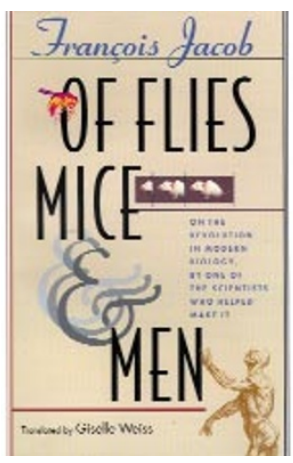

tainly the book does not present a detailed dissection of the pros and cons of the use of Drosophila melanogaster (the 'workbench' of early classical genetics and subsequently of developmental biology) or the mouse (the preferred model system for studying mammalian development and cell differentiation and probably the preferred future choice for the study and dissection of complex genetic traits). Much more than of flies and mice, this book is really about men, a fortunate and successful group of scientists, Jacob among them.

Of Flies, Mice and Men will most likely appeal to lay readers interested in science; those perhaps eager to find behavior and physiology, to biochemistry, biophysics, molecular biology and medicine. Thus, genetics has escaped from its classical boundaries, and in doing so has become a core unifying element of biology.

Scientistslooking for a precise historical account of the development and principles of molecular genetics may not find this short book wholly satisfying. The exposition of biological principles is simplified, and important fields, such as plant genetics, are clearly missing. Unfortunately, some extraordinary scientific milestones, such as Barbara M CClintock's discovery of transposable DNA el ements, are skipped. Thetitleis alittlemisleading; cer-

\title{
The Baltimore Case
}

\section{by Daniel J. Kevles \\ W.W. Norton \& Company, \$29.95, 448 pp. ISDN 0-393-04103-4}

\section{Reviewed by Fintan R. Steele Science Editor \\ The Journal of Clinical Investigation Ann Arbor, Michigan 48109, USA email: fintan@umich.edu}

Despite the rush to fill its sizable Thursday night void, the National Broadcasting Company (NBC) has not managed to replace "Seinfeld". Each episode of that lamented and brilliant show was the perfect wedding of writing and casting, offering the observant viewer frequent shocks of self-recognition. Perhaps the NBC executives should look to The Baltimore Case by Daniel J. Kevles for inspiration. This book could an approachableintroduction to molecular biology and genetics, and students hoping to embrace biology or 'molecular medicine' as a career. They will find a rather romantic account of important milestones in modern biology. Unfortunately, contemporary science is too often seen as a forbidding and fiercely competitive production line. Will the unrelenting pressure to publish yet more papers and acquire yet more grant money select in the future only for cold, narrow, pragmatic scientists? One can only hope that the world of science will, in the future, still be able to make room for broader individuals, like Jacob, who are more likely to enjoy the journey.

be the script for a worthy successor that would eclipse even Seinfeld in its sheer inventiveness. But it is not clear whether The Baltimore Case, which had its run in 'real life' from 1986 to 1996, is tragedy or comedy.

An accomplished scientific historian, Kevles expertly relates the story of a scientist accused of fraud by one of her postdoctoral fellows. This unexciting premise is nevertheless ground zero of a ten-year war waged from the towers of academia to the halls of government. At stake is the assertion of science that it can police itself, and the disbelief of its chief benefactor, the federal government. Indeed, the stakes are much higher than a simple case of alleged fraud, and it is thus no surprise to see powerful figures array themselves on both sides of the battlefield. This is perhaps what makes this book most compelling. In his cast of characters, Kevles captures perfectly the jumbled threads of hubris and humility 